\author{
Katarzyna Stabryla-Chudzio \\ Uniwersytet Ekonomiczny w Krakowie
}

\title{
Wpływ wydatków budżetowych na zmniejszanie ubóstwa w Polsce
}

\section{IMPACT OF PUBLIC EXPENDITURE ON REDUCING POVERTY IN POLAND}

\begin{abstract}
Problem ubóstwa $i$ wykluczenia spolecznego stat się niezwykle ważny $w$ następstwie kryzysu finansowego i gospodarczego z 2008 roku. Opracowanie koncentruje się na ocenie wdrażanych instytucjonalno-prawnych form pomocy w Polsce. Głównym celem opracowania jest identyfikacja rodzajów wydatków budżetowych zwiazanych z analizowanym zagadnieniem i zbadanie zależności pomiędzy wydatkami z budżetu państwa na realizację zadań zwiqzanych z pomoca spoleczna a zasięgiem ubóstwa $w$ Polsce. W rezultacie przeprowadzonych badań $z$ wykorzystaniem analizy statystycznej stwierdzono, że wzrost wydatków publicznych wplywa na poziom ubóstwa w Polsce zmniejszajac jego zasięg. W ramach wniosków płynacych $z$ badań odnotowano, że liniowe zależności między wydatkami z budżetu państwa $w$ działach dotyczqcych pomocy społecznej i rodziny a dwoma zmiennymi zależnymi będacymi wskaźnikami ubóstwa (skrajnego i relatywnego) sq statystycznie istotne i sq to zależności silne badź umiarkowane.
\end{abstract}

Słowa kluczowe: polityka finansowa państwa, ubóstwo, wykluczenie społeczne, pomoc społeczna.

JEL Codes: G28, H53, I38.

\section{Wstęp}

Problem ubóstwa i wykluczenia społecznego stał się niezwykle ważny w następstwie kryzysu finansowego i gospodarczego z 2008 roku. W Strategii "Europa 2020", przyjęto cel, w ramach którego liczba osób zagrożonych ubóstwem i wykluczeniem społecznym ma ulec obniżeniu o co najmniej 20 milionów w porównaniu z rokiem 2008. Działania realizowane $\mathrm{w}$ Polsce są zgodne $\mathrm{z}$ celami polityki Unii Europejskiej i znajdują odzwierciedlenie w licznych dokumentach rządowych. Na poziomie operacyjnym wdrażane są nowe rozwiązania prawne i instrumenty finansowe, które mają służyć realizacji celów przyjętych $\mathrm{w}$ obszarze ograniczenia ubóstwa i wykluczenia finansowego. W tym miejscu rodzą się zatem dwa pytania leżące u podstaw podjętego w opracowaniu problemu badawczego: 1) Jakie są podstawowe cele polityki społecznej w zakresie ograniczania ubóstwa i wykluczenia społecznego w Polsce? 2) Czy implementowane do polityki społecznej rozwiązania mają wpływ na zasięg ubóstwa?

Na podstawie tak wyrażonego problemu badawczego określone zostały główne cele opracowania, jakimi są: 1) charakterystyka wybranych elementów polityki fiskalnej 
państwa w zakresie przeciwdziałania problemowi ubóstwa i wykluczenia społecznego; 2) identyfikacja rodzajów wydatków budżetowych związanych $\mathrm{z}$ badanym zagadnieniem; 3) zbadanie zależności pomiędzy wydatkami $\mathrm{z}$ budżetu państwa na realizację zadań związanych z pomocą społeczną, a zasięgiem ubóstwa w Polsce.

Metody badawcze zastosowane w opracowaniu obejmują, w części przeglądowej krytyczną analizę piśmiennictwa oraz syntezę płynących z niej wniosków, w części empirycznej - analizę danych. W badaniach wykorzystano narzędzia statyczne, w tym statystykę opisową i metody wnioskowania statycznego.

Struktura opracowania jest pochodną wymienionych wyżej celów. Część pierwsza obejmuje przegląd piśmiennictwa. Część druga zawiera rozważania dotyczące polityki fiskalnej państwa w obszarze ubóstwa i wykluczenia społecznego. W części trzeciej omówiono metodykę przeprowadzonych badań oraz zaprezentowano ich rezultaty, co pozwoliło na udzielenie odpowiedzi na postawione pytania badawcze. Opracowanie kończy podsumowanie, w którym zawarto najważniejsze wnioski płynące z przeprowadzonych analiz oraz wskazano potencjalne kierunki dalszych badań.

\section{Podstawy teoretyczne ubóstwa i wykluczenia społecznego}

$\mathrm{W}$ latach 60. ubiegłego wieku ubóstwo łączyło się $\mathrm{z}$ brakiem zaspokojenia podstawowych potrzeb. Jednak $\mathrm{z}$ czasem definicja została rozszerzona o aspekty niefinansowe'. Zatem, jak podkreśla Sen, ubóstwo oznacza nie tylko brak wystarczających środków finansowych (bieżących i skumulowanych zasobów), ale także niemożność osiagnięcia pożądanych przez jednostki sposobów funkcjonowania, które pozwalają na prowadzenie przez nie odpowiadającego im stylu życia ${ }^{2}$.

Zachęcanie państw członkowskich UE do konkretnych działań w zakresie polityki społecznej, w tym propagowanie zwalczania ubóstwa i wykluczenia społecznego, choć sięga początków funkcjonowania Europejskiego Funduszu Społecznego, a następnie polityki strukturalnej od lat 80., to jednak najmocniej zostało zaakcentowane w roku 2000 w Strategii lizbońskiej i w 2010 r. w strategii Europie 2020³. Według Komisji Europejskiej ubóstwo obejmuje „,brak dochodów i wystarczających zasobów materialnych, by żyć w godności, nieodpowiedni dostęp do podstawowych usług, takich jak opieka zdrowotna, mieszkalnictwo i edukacja, wykluczenie z rynku pracy i niską jakość pracy"4. Ponadto Komisja Europejska stwierdza, że wykluczenie społeczne można zdefiniować jako „proces, w ramach którego niektóre osoby są spychane na margines społeczeństwa i nie mogą w pełni uczestniczyć w różnego rodzaju działaniach ze względu na swoje ubóstwo, brak podstawowych kompetencji i wykształcenia lub w wyniku różnych form

\footnotetext{
1 T. Panek, J. Zwierzchowski: Porównawcza analiza sfery ubóstwa w krajach UE w ujęciu regionalnym, Zeszyty Naukowe Instytutu Statystyki i Demografii SGH, Warszawa 2013, 35, s. 1-117.

${ }^{2}$ A. Sen: Social Exclusion: concept, application and scrutiny. Social Development Papers, 1, Manila: Asian Development Bank, 2000, s. 1-54.

${ }^{3}$ Por. M. Tkaczuk: Polska polityka społeczna na progu członkostwa w Unii Europejskiej, „Roczniki Nauk Społecznych" 2006, zeszyt 3, tom XXXIV, s. 211.

4 Komisja Europejska: Europejska platforma współpracy w zakresie walki z ubóstwem i wykluczeniem społecznym: europejskie ramy na rzecz spójności społecznej i terytorialnej, Komunikat Komisji do Parlamentu Europejskiego, Rady, Europejskiego Komitetu Ekonomiczno-Społecznego oraz Komitetu Regionów, $\operatorname{KOM}(2010) 758$ wersja ostateczna, Bruksela 2010, s. 6.
} 
dyskryminacji”. W efekcie osoby wykluczone „mają niewielki dostęp do organów decyzyjnych i często czują się bezsilne i niezdolne do przejęcia kontroli nad decyzjami mającymi wpływ na ich codzienne życie"

W związku z tym ubóstwo jest uwzględnione w wykluczeniu społecznym i może stać się czynnikiem prowadzącym do wykluczenia społecznego poprzez wyłączenie lub ograniczenie uczestnictwa $\mathrm{w}$ życiu społecznym ${ }^{7}$. Należy jednak podkreślić, że wykluczenie społeczne jest również możliwe pomijając czynnik ubóstwa ${ }^{8}$. Wśród przyczyn ubóstwa i wykluczenia społecznego Balcerzak-Paradowska wymienia te, które stanowią indywidualnie o człowieku (charakter, zdolności, postawa życiowa, wiek, zdrowie) jak i te niezależne od jednostki (czynniki egzogeniczne jak niewydolność systemu społeczno-gospodarczego) ${ }^{9}$. Wydaje się jednak, że obie grupy często są ze sobą tak ściśle powiązane, że pojawia się wyraźna trudność w ich rozdzieleniu.

Państwo poprzez narzędzia finansowe, regulacyjne i systemowe powinno dążyć do zapewnienia minimalnego standardu życia osób i rodzin ${ }^{10}$. W kontekście ubóstwa $\mathrm{i}$ ewentualnie związanego $\mathrm{z}$ nim (będącego jego konsekwencją) wykluczenia społecznego w dużej mierze wykorzystuje się politykę socjalną jako część i instrument polityki społecznej w formie świadczeń społecznych, a zatem transferów pieniężnych ${ }^{11}$.

Zgodnie $\mathrm{z}$ art. 2 ustawy o pomocy społecznej, pomoc społeczna jest traktowana jako instytucja polityki społecznej państwa. Państwo, z racji posiadanych uprawnień, zasobów i możliwości, pomaga osobom i rodzinom w przezwyciężaniu trudnych sytuacji życiowych, których nie są one $\mathrm{w}$ stanie same pokonać ${ }^{12}$. Zapisy ustawowe można połączyć z treścią art. 71 Konstytucji RP mówiącego o uwzględnianiu przez państwo w polityce gospodarczej i społecznej dobra rodziny ${ }^{13}$. Ponadto do szczególnej pomocy ze strony władz publicznych są uprawnione rodziny w trudnej sytuacji materialnej i społecznej, zwłaszcza wielodzietne i niepełne, oraz matki przed i po urodzeniu dziecka. W literaturze przedmiotu można zatem zauważyć wyróżnienie z polityki społecznej polityki rodzinnej ${ }^{14}$.

\footnotetext{
${ }^{5}$ Eurostat: Smarter, greener, more inclusive? Indicators to support the Europe 2020 strategy, Publications Office of the European Union, Luxembourg 2016.

${ }^{6}$ Eurostat: op. cit..

${ }^{7}$ B. Balcerzak-Paradowska: Ogólne tendencje w polityce rodzinnej UE, [w:] Polityka rodzinna w krajach Unii Europejskiej - wnioski dla Polski, B. Balcerzak-Paradowska, J. Szymborski (red.), Biuletyn Rzecznika Praw Obywatelskich - Materiały Nr 67, Warszawa 2009, s. 115; A. Sen, op. cit.

${ }^{8}$ M. Lecerf: Poverty in the European Union. The crisis and its aftermath, European Parliamentary Research Service, European Parliament: Directorate-General for Parliamentary Research Services, European Union 2016.

9 B. Balcerzak-Paradowska: Rodzina i polityka rodzinna na przełomie wieków: przemiany, zagrożenia potrzeba działań, Instytut Pracy i Spraw Socjalnych, Warszawa 2004, s. 116.

${ }^{10}$ S. Stecko: Polityka społeczna państwa względem rodziny, „Społeczeństwo i Rodzina” 2017, Nr 50, s. 139151; R. Szarfenberg: Ubóstwo i wykluczenie społeczne w Polsce. Pomiar, wyjaśnianie, strategie przeciwdziałania, Friedrich-Ebert-Stiftung, Przedstawicielstwo w Polsce wspólnie z Fundacją Międzynarodowe Centrum Badań i Analiz (ICRA ), Warszawa 2012, s. 115-117; B. Szatur-Jaworska: Polityka socjalna [w:] W kręgu pojęć i zagadnień współczesnej polityki społecznej, B. Rysz-Kowalczyk, B. Szatur-Jaworska (red.), Instytut Polityki Społecznej, Wydawnictwo Uniwersytetu Warszawskiego, Warszawa 2016, s. 51-57.

${ }_{11}^{11}$ J. Supińska: Debaty o polityce społecznej, Oficyna Wydawnicza ASPRA-JR, Warszawa 2013, s. 14.

${ }^{12}$ Ustawa z dnia 12 marca 2004 r. o pomocy społecznej, Dz. U. 2004, nr 64, poz. 593 ze zm.

${ }^{13}$ Konstytucja Rzeczypospolitej Polskiej z dnia 2 kwietnia 1997 r., Dz.U. 1997, nr 78, poz. 483.

${ }^{14}$ A. Kurzynowski: Problemy rodziny w polityce społecznej, Ośrodek Badań Społecznych, Warszawa 1991, s. 96; B. Balcerzak-Paradowska: Rodzina i polityka rodzinna...op .cit., s. 139.
} 
Do instrumentów polityki społecznej można zaliczyć świadczenia pieniężne, świadczenia niepieniężne ( $\mathrm{w}$ tym pomoc rzeczowa) usługi społeczne, preferencje podatkowe, rozwiązania prawno-instytucjonalne ${ }^{15}$. W modelu konserwatywnym i socjaldemokratycznym państwo bierze na siebie istotny obowiązek poprawy warunków i jakości życia ludności kierując się zasadą egalitaryzmu (wyrównywania szans w sensie ekonomicznym i społecznym głównie grup najsłabszych) i solidaryzmu społecznego w celu rozwoju całego społeczeństwa ${ }^{16}$. Jednak nie można zapominać o indywidualnym postrzeganiu otrzymywanych świadczeń przez obywateli i konieczności tzw. gradualizmu, czyli dostosowania pomocy do sytuacji jednostki, gospodarstwa domowego czy rodziny ${ }^{17}$. W efekcie generalizacja pomocy w celu zwalczania ubóstwa i wykluczenia społecznego poprzez wzrost nakładów finansowych, czego przykładem jest świadczenie na dziecko w Polsce pomijając kryterium dochodowe, może prowadzić do roszczeniowości i pozbawienia samodzielności życiowej coraz większej grupy osób. Zaznacza się jednocześnie, że nie chodzi o zaspokojenie wszystkich potrzeb oraz że jednym z głównych celów państwa powinno być tutaj dążenie do usamodzielnienia się osób otrzymujących wsparcie, a zatem wsparcie powinno mieć charakter tymczasowy ${ }^{18}$.

\section{Polityka przeciwdziałania ubóstwu i wykluczeniu społecznemu w Polsce}

Jak podkreślono wcześniej skala zagrożenia ubóstwem/wykluczeniem społecznym jest uzależniona od działania czynników zewnętrznych, które w wielu przypadkach są niezależne od kształtu polityki społecznej państwa. Do czynników tych zaliczyć należy m.in. poziom rozwoju gospodarczego oraz perspektywy w tym zakresie, zróżnicowanie w poziomie rozwoju pomiędzy regionami oraz czynniki społeczne i kulturowe.

Skoordynowana polityka Polski na rzecz rozwoju kraju, w tym na rzecz walki $\mathrm{z}$ ubóstwem została zawarta $\mathrm{w}$ szeregu dokumentów rządowych odnoszących się do strategii Europa 2020. W celu przeciwdziałania problemom ubóstwa i wykluczenia społecznego Polska przyjęła priorytet zgodny ze strategią Europa 2020, iż najlepszym sposobem na radzenie sobie $\mathrm{z}$ tym problemem jest podejmowanie pracy zarobkowej ${ }^{19}$. W Strategii Rozwoju Kraju 2020 w jednym z trzech obszarów strategicznych, odnoszącym się do spójności społecznej i terytorialnej wskazano priorytetowe kierunki

\footnotetext{
${ }^{15}$ B. Balcerzak-Paradowska: Rodzina i polityka rodzinna..., op. cit., s. 141-145; A. Durasiewicz: Instrumenty polityki rodzinnej, „Biuletyn Informacyjny. Wiadomości Społeczne” Nr 1, K. Głąbicka (red.), Polskie Towarzystwo Polityki Społecznej, Warszawa 2009, s. 57-70.

${ }^{16}$ Por. A. Kokoszkiewicz: Opieka społeczna jako zadanie państwa. Studium teoretycznoprawne, Wydawnictwo Europejskiej Fundacji Przedsiębiorczości, Lublin 2015, s. 33-42; A. Kurzynowski: Związki polityki społecznej z polityką gospodarczą [w:] Kurzynowski A. red. Polityka społeczna, Szkoła Główna Handlowa, Warszawa 2001, s. 10-11.

${ }^{17}$ J. Orczyk: Ewolucja polityki społecznej w Polsce po 1990 r., [w:] Współczesne obrazy polityki społecznej i gospodarczej. Księga pamiątkowa dedykowana Profesor Lucynie Frąckiewicz, „Studia Ekonomiczne”, Zeszyty Naukowe Wydziałowe Uniwersytetu Ekonomicznego w Katowicach, W. Koczur, A. Rączaszek (red.), Katowice 2012, s. 39-40.

${ }^{18}$ I. Sierpowska: Wprowadzenie [w:] Pomoc społeczna, Lex a Wolters Kluwer business, Warszawa 2011, s. 20-21; I. Sierpowska: Bezpieczeństwo socjalne jako dobro publiczne, Zeszyty Naukowe Państwowej Wyższej Szkoły Zawodowej im. Witelona w Legnicy 2015, Nr 16(3), s. 49-54.

${ }^{19}$ Komisja Europejska: op. cit.
} 
interwencji publicznej. Dotyczą one ${ }^{20}$ : zwiększenia aktywności osób wykluczonych i zagrożonych wykluczeniem społecznym, zmniejszenia ubóstwa w grupach najbardziej zagrożonych oraz zwiększenia bezpieczeństwa obywateli. Strategia Rozwoju Kraju obowiązywała do 2017 r. W marcu 2017 r. zaczęła obowiązywać Strategia na rzecz Odpowiedzialnego Rozwoju do roku 2020 (z perspektywą do 2030 r. . $^{21}$. Tak jak w przypadku wcześniej obowiązującej strategii, jednym z głównych celów strategii w perspektywie długookresowej jest wzrost dochodów obywateli oraz poprawa jakości życia rozumiana jako stworzenie przyjaznych warunków bytowych, przede wszystkim dla rodzin; zapewnienie odpowiedniej jakości edukacji i szkoleń, podwyższających kwalifikacje i kompetencje obywateli; wzrost zatrudnienia i lepsze jakościowo miejsca pracy; poprawa dostępu do infrastruktury; zapewnienie odpowiedniej opieki medycznej, poprawiającej zdrowotność obywateli, a także satysfakcjonującego stanu środowiska oraz poczucia bezpieczeństwa ${ }^{22}$.

Jednocześnie w kluczowym z punktu widzenia realizacji strategii Europa 2020 dokumencie rządowym, tj. Krajowym Programie Reform wskazano, że jest to proces długofalowy, który wymaga działań podejmowanych zarówno na szczeblu centralnym jak i samorządowym. Będzie on realizowany $w$ ramach aktywności dla wzrostu sprzyjającego włączeniu społecznemu $\mathrm{w}$ dwóch obszarach, tj. tworzenia nowoczesnego rynku pracy i przeciwdziałania wykluczeniu społecznemu ${ }^{23}$.

„Budowa nowoczesnego rynku pracy sprzyjającego wzrostowi gospodarczemu musi podazżać w kierunku wzmacniania wszystkich elementów modelu flexicurity. Głównym priorytetem jest odpowiedź na wyzwania związane $\mathrm{z}$ przemianami demograficznymi, jakie ujawnią się w przeciagu kilku najbliższych lat poprzez działania służące zwiększaniu zatrudnienia” ${ }^{24}$. Z kolei działania na rzecz ograniczenia skali ubóstwa i wykluczenia społecznego koncentrują się w znacznej mierze na zwiększaniu szans na zatrudnienie osób defaworyzowanych na rynku pracy (osób młodych, o niskim poziomie wykształcenia, o złym stanie zdrowia, niepełnosprawnych, osób migrujących). Osoby i rodziny dotknięte bezrobociem i biernością zawodową są najbardziej narażone na ryzyko ubóstwa i wykluczenia społecznego. Wynika to $\mathrm{z}$ przekonania, iż przeciwdziałanie i walka z ubóstwem może się dokonywać efektywnie głównie przez rynek pracy. W celu poprawy sytuacji osób wykluczonych społecznie $\mathrm{z}$ powodu ubóstwa, zwiększany będzie również zakres aktywnych form przeciwdziałania wykluczeniu społecznemu i integracji społecznej osób wykluczonych ${ }^{25}$.

Efektywne przeciwdziałanie tym problemom wymaga również aktywności ze strony osób zagrożonych ryzykiem ubóstwa i wykluczenia społecznego, wzmocnionych przez odpowiednie wyposażenie ich do samodzielnego wychodzenia $\mathrm{z}$ ubóstwa i wykluczenia społecznego (empowerment oraz bottom up process). Ponadto proces ten nie może być efektywnie realizowany bez uwzględnienia, innych, poza

\footnotetext{
${ }^{20}$ Rada Ministrów: Uchwała Nr 157 Rady Ministrów z dnia 25 września 2012 r. w sprawie przyjęcia Strategii Rozwoju Kraju 2020, M. P. 2012, poz. 882

${ }^{21}$ Rada Ministrów: Uchwała nr 8 Rady Ministrów z dnia 14 lutego 2017 r. w sprawie przyjęcia Strategii na rzecz Odpowiedzialnego Rozwoju do roku 2020 (z perspektywą do 2030 r.), M.P. 2017 poz. 260.

${ }^{23}$ Rada Ministrów: Krajowy Program Reform, Warszawa 2011.

${ }^{24}$ Ibidem, s. 41.

${ }^{25}$ Ibidem, s. 44.
} 
ubóstwem, czynników wpływających na ryzyko czy nawet doprowadzających do wykluczenia społecznego, np. deprywacji materialnej, ograniczonego dostępu do usług zdrowotnych, edukacyjnych ${ }^{26}$. Wszystkie te elementy powoduja, że podejmowane działania dla realizacji celu wzrostu zatrudnienia, jak i celu redukcji ubóstwa w ramach strategii Europa 2020 będą się wzajemnie uzupełniać.

Z punktu widzenia realizacji Strategii Rozwoju Kraju 2020 oraz Strategii na rzecz Odpowiedzialnego Rozwoju w obszarze ubóstwa i wykluczenia społecznego szczególne znaczenie ma „Krajowy Program Przeciwdziałania Ubóstwu i Wykluczeniu Społecznemu 2020. Nowy wymiar aktywnej integracji,"27. Jest to dokument o charakterze operacyjno-wdrożeniowym, ustanowiony $\mathrm{w}$ celu realizacji średniookresowej strategii rozwoju kraju - „Strategii Rozwoju Kraju 2020”, Strategii Rozwoju Kapitału Społecznego ${ }^{28}$, Strategii Rozwoju Kapitału Ludzkiego ${ }^{29}$, oraz innych strategii rozwoju. W kontekście nowej metodologii programowania polityk publicznych, za istotny element uznano wyodrębnienie problematyki ubóstwa i wykluczenia społecznego, jako części krajowych działań budowy Europejskiego Modelu Społecznego. Program został zapowiedziany w przyjętym przez Radę Ministrów 30 kwietnia 2013 roku, Krajowym Programie Reform na rzecz realizacji strategii „Europa 2020” - Aktualizacja KPR 2013/2014 . Tym samym, stanowi on realizację krajowej polityki społecznej i obejmuje 6 priorytetów: przeciwdziałanie wykluczeniu społecznemu dzieci i młodzieży, zapewnienie spójności działań edukacyjnych, społecznych i zawodowych na rzecz dzieci i młodzieży, aktywną integrację w społeczności lokalnej, bezpieczeństwo i aktywność osób starszych, zapobieganie niepewności mieszkaniowej oraz zarządzanie i zmiany strukturalne systemu integracji społecznej.

Na poziomie operacyjnym realizowana polityka znajduje odzwierciedlenie m.in. w poziomie wydatków związanych $\mathrm{z}$ ograniczaniem ubóstwa $\mathrm{i}$ wykluczenia społecznego. $Z$ racji ograniczonych ram opracowania badaniem objęto wydatki rządowe w działach Pomoc spoleczna (dział 852) oraz Pozostałe zadania w zakresie polityki społecznej (dział 853) w okresie 2008-2017 oraz dziale Rodzina (dział 855) (od 2017 roku) pomijając preferencje podatkowe oraz wydatki na politykę społeczną ujęte w innych działach klasyfikacji budżetowej.

Zgodnie z uzasadnieniem do projektu ustawy budżetowej na rok 2008, system pomocy społecznej ma na celu ,wsparcie materialne niezamożnych rodzin z dziećmi na utrzymaniu, pomoc osobom $\mathrm{i}$ rodzinom $\mathrm{w}$ przezwyciężaniu trudnych sytuacji życiowych, których nie są w stanie pokonać przy wykorzystaniu własnych środków, uprawnień i możliwości, doprowadzenie do życiowego usamodzielnienia osób i rodzin,

\footnotetext{
${ }^{26}$ Rada Ministrów: Krajowy Program Reform...op. cit., s. 52.

${ }^{27}$ Rada Ministrów: Uchwała Rady Ministrów nr 165 z dnia 12 sierpnia 2014 r. w sprawie przyjęcia programu pod nazwą „Krajowy Program Przeciwdziałania Ubóstwu i Wykluczeniu Społecznemu 2020. Nowy wymiar aktywnej integracji”, M.P. 2014, poz. 787.

${ }^{28}$ Rada Ministrów: Uchwała Nr 61 Rady Ministrów z dnia 26 marca 2013 r. w sprawie przyjęcia „Strategii Rozwoju Kapitału Społecznego 2020”, M.P. 2013, poz. 378.

${ }^{29}$ Rada Ministrów: Uchwała Nr 104 Rady Ministrów z dnia 18 czerwca 2013 r. w sprawie przyjęcia Strategii Rozwoju Kapitału Ludzkiego 2020, M.P. 2013, poz. 640.

${ }^{30}$ Rada Ministrów: Krajowy Program Reform na rzecz realizacji strategii „Europa 2020” - Aktualizacja KPR 2013/2014, Warszawa 2013.
} 
a także do ich integracji ze środowiskiem" ${ }^{\text {31 }}$. Zatem wydatki na pomoc społeczną i rodzinę mają służyć ograniczeniu ubóstwa, zmniejszeniu zróżnicowania dochodowego w społeczeństwie, zwłaszcza wśród rodzin z dziećmi, przezwyciężeniu trudnej sytuacji życiowej osób i rodzin, w tym pomoc osobom potrzebującym opieki innych osób. W konsekwencji wsparcie państwa powinno polegać $\mathrm{na}^{32}$ :

- udzielaniu pomocy materialnej,

- umożliwianiu łączenia funkcji rodzicielskich z pracą zawodową poprzez rozwiązania systemowe (dostęp do placówek publicznych opieki nad dzieckiem, elastyczne formy zatrudnienia, ruchomy czas pracy),

- przeciwdziałaniu przemocy w rodzinie,

- udzielaniu profesjonalnej pomocy ofiarom przemocy w rodzinie oraz oddziaływaniu na sprawców przemocy,

- doskonaleniu rozwiązań związanych z adopcja,

- prowadzeniu badań z zakresu polityki rodzinnej i równego statusu kobiet i mężczyzn,

- dążeniu do poprawy standardów w istniejących placówkach opiekuńczowychowawczych.

Finansowanie pomocy materialnej obejmuje wypłaty: świadczeń rodzinnych (zasiłku rodzinnego i dodatków do zasiłku rodzinnego, jednorazowej zapomogi z tytułu urodzenia się dziecka wypłacanej bez względu na dochód uzyskiwany przez rodzinę, zasiłku pielęgnacyjnego i świadczeń pielęgnacyjnych), zaliczek alimentacyjnych (a od 1 października 2008 r. świadczeń z funduszu alimentacyjnego), a także składek na ubezpieczenia emerytalne i rentowe $\mathrm{z}$ ubezpieczenia społecznego opłacanych za osoby pobierające świadczenia pielęgnacyjne, wypłatę rent socjalnych, zapomóg pieniężnych oraz świadczeń i zasiłków przedemerytalnych, pomoc dla kombatantów i osób uprawnionych, wypłatę zasiłków celowych dla osób i rodzin poszkodowanych w wyniku niekorzystnych zjawisk atmosferycznych. Dodatkowo z budżetu państwa dokonuje się wypłaty środków na usługi opiekuńcze dla osób wymagających pomocy osób trzecich, pomoc dla cudzoziemców i repatriantów oraz pomoc dla Polonii i Polaków za granica.

W początkowym okresie analizy (lata 2008-2011) zaobserwowano spadek wydatków w dziale Pomoc społeczna, wynikający m.in. ze spadku liczby świadczeniobiorców i z przejęcia przez Fundusz Pracy obowiązków związanych z finansowaniem zasiłków i świadczeń przedemerytalnych wraz z kosztami obsługi. Odwrócenie tendencji nastapiło w 2012 r. (tabela 1). Stopniowy wzrost wydatków w okresie 2012-2015 wynikał przede wszystkim ze wzrostu dotacji dla jednostek samorządu terytorialnego przekazywanych głównie $\mathrm{na}^{33}$ :

- wypłaty świadczeń rodzinnych (zasiłku rodzinnego i dodatków do tego zasiłku, zasiłku i świadczeń pielęgnacyjnych), zasiłków stałych, świadczeń z funduszu alimentacyjnego oraz kosztów ich obsługi,

- działalność ośrodków i domów pomocy społecznej,

\footnotetext{
${ }^{31}$ Rada Ministrów: Uzasadnienie do projektu ustawy budżetowej w układzie zadaniowym na rok 2008, Warszawa 2008.

${ }^{32}$ Rada Ministrów: Uzasadnienie do projektu ustawy budżetowej w układzie zadaniowym na lata 2008-2019, Warszawa 2007-2018.

${ }^{33}$ Rada Ministrów: Sprawozdanie z wykonania budżetu państwa za lata 2012-2015, Warszawa 2013-2016.
} 
- opłacenie składki na ubezpieczenie zdrowotne za osoby pobierające świadczenie rodzinne, oraz zasiłki stałe, a także za osoby objęte indywidualnym programem zatrudnienia socjalnego oraz za osoby bezdomne objęte indywidualnym programem wychodzenia z bezdomności,

- usuwanie skutków klęsk żywiołowych poprzez wypłatę zasiłków celowych dla osób i rodzin poszkodowanych w okresie 2010-2015,

- realizację przez wszystkie województwa rządowego programu wieloletniego „Pomoc państwa w zakresie dożywiania",

- zadania w zakresie przeciwdziałania przemocy w rodzinie.

Tabela 1. Wydatki z budżetu państwa na zadania z zakresu polityki społecznej i w dziale Rodzina

\begin{tabular}{|c|c|c|c|c|c|c|c|c|c|c|c|}
\hline $\begin{array}{l}\text { Wydatki z } \\
\text { budżetu } \\
\text { państwa }\end{array}$ & 2008 & 2009 & 2010 & 2011 & 2012 & 2013 & 2014 & 2015 & 2016 & 2017 & $\begin{array}{l}\text { Dynamika } \\
2017 / 2008\end{array}$ \\
\hline $\begin{array}{l}\text { Wydatki na } \\
\text { pomoc } \\
\text { społeczną i } \\
\text { rodzinę (w } \\
\text { mld zł), w } \\
\text { tym: }\end{array}$ & 18,33 & 15,99 & 17,09 & 16,49 & 17,41 & 17,86 & 18,18 & 18,57 & 39,32 & 48,16 & 2,63 \\
\hline $\begin{array}{l}\text { Pomoc } \\
\text { spoteczna } \\
\text { (w mld zł) }\end{array}$ & 12,96 & 12,50 & 14,16 & 13,42 & 13,93 & 14,25 & 14,48 & 14,69 & 34,23 & 4,70 & 0,36 \\
\hline $\begin{array}{l}\text { Rodzina } \\
\text { (w mld zł) }\end{array}$ & 0,00 & 0,00 & 0,00 & 0,00 & 0,00 & 0,00 & 0,00 & 0,00 & 0,00 & 39,29 & - \\
\hline $\begin{array}{l}\text { Pozostate } \\
\text { zadania z } \\
\text { zakresu } \\
\text { opieki } \\
\text { społecznej } \\
\text { (w mld zł) }\end{array}$ & 5,37 & 3,49 & 2,94 & 3,08 & 3,48 & 3,61 & 3,70 & 3,88 & 5,09 & 4,16 & 0,77 \\
\hline $\begin{array}{l}\text { Wydatki } \\
\text { ogółem }\end{array}$ & 277,89 & 298,03 & 294,89 & 302,68 & 318,00 & 321,35 & 312,52 & 331,74 & 360,84 & 375,77 & 1,35 \\
\hline $\begin{array}{l}\text { Udział } \\
\text { wydatków na } \\
\text { pomoc } \\
\text { społeczną i } \\
\text { rodzinę w } \\
\text { wydatkach } \\
\text { ogółem; }\end{array}$ & $6,6 \%$ & $5,4 \%$ & $5,8 \%$ & $5,4 \%$ & $5,5 \%$ & $5,6 \%$ & $5,8 \%$ & $5,6 \%$ & $10,9 \%$ & $12,8 \%$ & 1,94 \\
\hline
\end{tabular}

Źródło: opracowanie własne na podstawie: Rada Ministrów: Sprawozdanie z wykonania budżetu państwa za lata 2008-2017, Warszawa 2009-2018.

Od 2015 roku realizowany jest również program wieloletni „Senior+”, którego celem jest zachęcanie osób starszych do aktywnego uczestnictwa w życiu społecznym poprzez rozbudowę infrastruktury ośrodków wsparcia w środowisku lokalnym oraz zwiększenie miejsc w placówkach "Senior+" takich jak kluby i dzienne domy „Senior+”. Od tego samego roku pojawiły się również działania związane z realizacją zadań wynikających z ustawy o Karcie Dużej Rodziny ${ }^{34}$.

${ }^{34}$ Ustawa z dnia 5 grudnia 2014 r. o Karcie Dużej Rodziny, Dz. U. 2014, poz. 1863 ze zm. 
Znaczący wzrost wydatków od 2016 roku wynikał z realizacji nowego Programu „Rodzina 500+”, którego celem jest przeciwdziałanie ubóstwu i wykluczeniu społecznemu rodzin z dziećmi oraz negatywnemu trendowi demograficznemu w Polsce (dział 852) (tabela 1$)^{35}$. Natomiast w dziale 853 wzrost wydatków był spowodowany wypłatą jednorazowego dodatku pieniężnego dla niektórych emerytów, rencistów i osób pobierających świadczenia przedemerytalne, zasiłki przedemerytalne, emerytury pomostowe lub nauczycielskie świadczenia kompensacyjne. Ponadto w 2017 roku zwiększono wydatki na realizację świadczeń rodzinnych, głównie na kolejny etap weryfikacji świadczeń (podwyższenie kryteriów dochodowych oraz zasiłków rodzinnych) i kontynuowano działania w zakresie zwiększenia dostępności wychowania przedszkolnego. Od 2017 roku zaczęto wypłacać także jednorazowe świadczenie, wynikające $\mathrm{z}$ ustawy o wsparciu kobiet $\mathrm{w}$ ciąży i rodzin ${ }^{36}$.

W 2017 roku nastapił istotny spadek dochodów w obu analizowanych działach, a w szczególności w dziale 852 (tabela 1). Niższe wydatki wynikały jednak z utworzenia nowego działu 855 Rodzina i przeniesienia do niego świadczeń rodzinnych, finansowania żłobków i klubów dziecięcych oraz realizacji programu „Rodzina 500+”.

W celu oceny wpływu zmian analizowanych wydatków publicznych na poziom ubóstwa posłużono się podstawową miarą oceniająca zasięg ubóstwa w Polsce tzw. stopą ubóstwa. Jest to odsetek osób w gospodarstwach domowych, w których poziom wydatków (obejmujących również wartość artykułów otrzymanych bezpłatnie oraz wartość spożycia naturalnego) był niższy od przyjętej granicy ubóstwa. W Polsce pomiaru zasięgu ubóstwa ekonomicznego, szacowanego w oparciu o wyniki badania budżetów gospodarstw domowych, dokonuje się przy zastosowaniu różnych granic ubóstwa. Uwzględnienie kilku granic wynika m.in. z faktu, iż żadna z granic nie została określona w Polsce jako granica urzędowa, a $\mathrm{z}$ metodologicznego punktu widzenia nie ma podstaw, aby bezspornie preferować którąs z nich ${ }^{37}$. Każda ma bowiem zalety i wady oraz odmienną interpretację. Granice ubóstwa w Polsce przedstawia tabela 2.

Tabela 2. Granice ubóstwa w Polsce

\begin{tabular}{|l|l|}
\hline $\begin{array}{c}\text { Granica } \\
\text { ubóstwa } \\
\text { ekonomicznego }\end{array}$ & \multicolumn{1}{c|}{ Definicja } \\
\hline $\begin{array}{l}\text { Granica } \\
\text { ubóstwa } \\
\text { skrajnego }\end{array}$ & $\begin{array}{l}\text { obliczana na podstawie minimum egzystencji, które szacowane jest przez Instytut Pracy i } \\
\text { Spraw Socjalnych (IPiSS). Uwzględnia ono jedynie te potrzeby, których zaspokojenie nie } \\
\text { może być odłożone w czasie, a konsumpcja niższa od tego poziomu prowadzi do } \\
\text { biologicznego wyniszczenia. }\end{array}$ \\
\hline $\begin{array}{l}\text { Ustawowa } \\
\text { granica ubóstwa }\end{array}$ & $\begin{array}{l}\text { określona jako kwota, która zgodnie z obowiązującą ustawą o pomocy społecznej } \\
\text { uprawnia do ubiegania się o przyznanie świadczenia pieniężnego z pomocy społecznej. }\end{array}$ \\
\hline $\begin{array}{l}\text { Relatywna } \\
\text { granica ubóstwa }\end{array}$ & $\begin{array}{l}\text { ustalona na poziomie 50\% średnich wydatków ogółu gospodarstw domowych } \\
\text { (obliczonych na podstawie wyników badania budżetów gospodarstw domowych). }\end{array}$ \\
\hline
\end{tabular}

Źródło: Główny Urząd Statystyczny: Zasięg ubóstwa ekonomicznego w Polsce w latach 2008-2017, Warszawa 2009-2018.

\footnotetext{
${ }^{35}$ Ustawa z dnia 11 lutego 2016 r. o pomocy państwa w wychowywaniu dzieci, Dz.U. 2016, poz. 195.

${ }^{36}$ Ustawa z dnia 4 listopada 2016 r. o wsparciu kobiet w ciąży i rodzin „Za życiem", Dz. U. 2016, poz. 1860 ze zm.

${ }^{37}$ Główny Urząd Statystyczny: Zasięg ubóstwa ekonomicznego w Polsce w latach 2016, Warszawa 2017.
} 
W przypadku ubóstwa skrajnego i relatywnego, w celu wyeliminowania wpływu, jaki na koszty utrzymania gospodarstw domowych wywiera ich struktura społecznodemograficzna, zarówno przy obliczaniu poziomu wydatków w gospodarstwach domowych, jak i ustalaniu granic ubóstwa, stosuje się tzw. oryginalną skalę ekwiwalentności $\mathrm{OECD}^{38}$. Według tej skali wagę 1 przypisuje się pierwszej osobie w gospodarstwie domowym w wieku 14 lat i więcej; 0,7 - każdej następnej osobie w tym wieku; 0,5 - każdemu dziecku w wieku poniżej 14 lat. Oznacza to, że granica ubóstwa dla gospodarstwa 4-osobowego złożonego z dwóch osób dorosłych i dwojga dzieci w wieku poniżej 14 lat jest 2,7 razy wyższa niż dla gospodarstwa 1-osobowego ${ }^{39}$. Wysokość granic ubóstwa stosowanych do pomiaru zasięgu ubóstwa ekonomicznego w Polsce przedstawia tabela 3.

Tabela 3. Granice ubóstwa dla wybranych typów gospodarstw domowych w latach 2008-2017

\begin{tabular}{|c|c|c|c|c|c|c|c|c|c|c|c|}
\hline $\begin{array}{l}\text { Granice } \\
\text { ubóstwa }\end{array}$ & 2008 & 2009 & 2010 & 2011 & 2012 & 2013 & 2014 & 2015 & 2016 & 2017 & $\begin{array}{l}\text { Dynamika } \\
2017 / 2008 \\
\end{array}$ \\
\hline \multicolumn{12}{|c|}{ Gospodarstwa 1-osobowe } \\
\hline $\begin{array}{l}\text { Skrajnego } \\
\text { (minimum } \\
\text { egzystencji) } \\
\text { (w zl) }\end{array}$ & 418 & 443 & 466 & 495 & 519 & 551 & 540 & 545 & 550 & 582 & 1,39 \\
\hline $\begin{array}{l}\text { Relatywnego } \\
\text { (w zl) }\end{array}$ & 612 & 633 & 665 & 690 & 691 & 706 & 713 & 734 & 770 & 799 & 1,31 \\
\hline $\begin{array}{l}\text { Ustawowego } \\
\text { (w zł) }\end{array}$ & 477 & 477 & 477 & 477 & 542 & 542 & 542 & 634 & 634 & 634 & 1,33 \\
\hline \multicolumn{12}{|c|}{ Gospodarstwa 4-osobowe ( 2 osoby dorosłe +2 dzieci do lat 14$)$} \\
\hline $\begin{array}{l}\text { Skrajnego } \\
\text { (minimum } \\
\text { egzystencji) } \\
\text { (w zl) }\end{array}$ & 1129 & 1196 & 1257 & 1336 & 1401 & 1486 & 1458 & 1472 & 1486 & 1571 & 1,39 \\
\hline $\begin{array}{l}\text { Relatywnego } \\
\text { (w zł) }\end{array}$ & 1676 & 1709 & 1795 & 1863 & 1866 & 1906 & 1926 & 1982 & 2080 & 2157 & 1,29 \\
\hline $\begin{array}{l}\text { Ustawowego } \\
\text { (w zł) }\end{array}$ & 1404 & 1404 & 1404 & 1404 & 1824 & 1824 & 1824 & 2056 & 2056 & 2056 & 1,46 \\
\hline
\end{tabular}

a - Poziom granic ubóstwa w IV kwartale

Źródło: opracowanie własne na podstawie danych GUS (Główny Urząd Statystyczny: Zasięg ubóstwa ekonomicznego w Polsce w latach 2008-2017, Warszawa 2009-2018).

W latach 2008-2017 wzrosły wszystkie granice wykorzystywane do pomiaru zasięgu ubóstwa ekonomicznego. W przypadku gospodarstw jednoosobowych największy wzrost nastąpił w przypadku granicy ubóstwa skrajnego i wyniósł on blisko $40 \%$. Granica ubóstwa ustawowego wzrosła natomiast o blisko 33\%. Jednak w początkowym okresie analizy (lata 2008-2011) utrzymywała się ona na stałym poziomie. Po okresie stagnacji dopiero od 2012 r. następował jej wzrost. Największy odnotowano w 2015 r., kiedy to w stosunku do roku poprzedniego granica ubóstwa ustawowego wzrosła o blisko 17\%. Wzrostowi granic ubóstwa towarzyszył spadek zasięgu ubóstwa ekonomicznego, co przedstawia wykres 1 .

${ }^{38}$ OECD: The OECD List of Social Indicators, OECD: Paris 1982.

39 Główny Urząd Statystyczny: Zasięg ubóstwa ekonomicznego w Polsce w latach 2008-2017, Warszawa 2009-2018. 
W badanych latach wyodrębnić można dwa okresy. Pierwszy obejmuje lata 20082013. Okres ten charakteryzował się powolnym spadkiem ubóstwa relatywnego, wzrostem ubóstwa skrajnego i dużymi wahaniami w przypadku zasięgu ubóstwa ustawowego. Natomiast w drugim okresie, począwszy od 2014 r. dominuje tendencja spadkowa w przypadku wszystkich trzech rodzajów ubóstwa (z wyjątkiem $2016 \mathrm{r}$. w przypadku ubóstwa ustawowego).

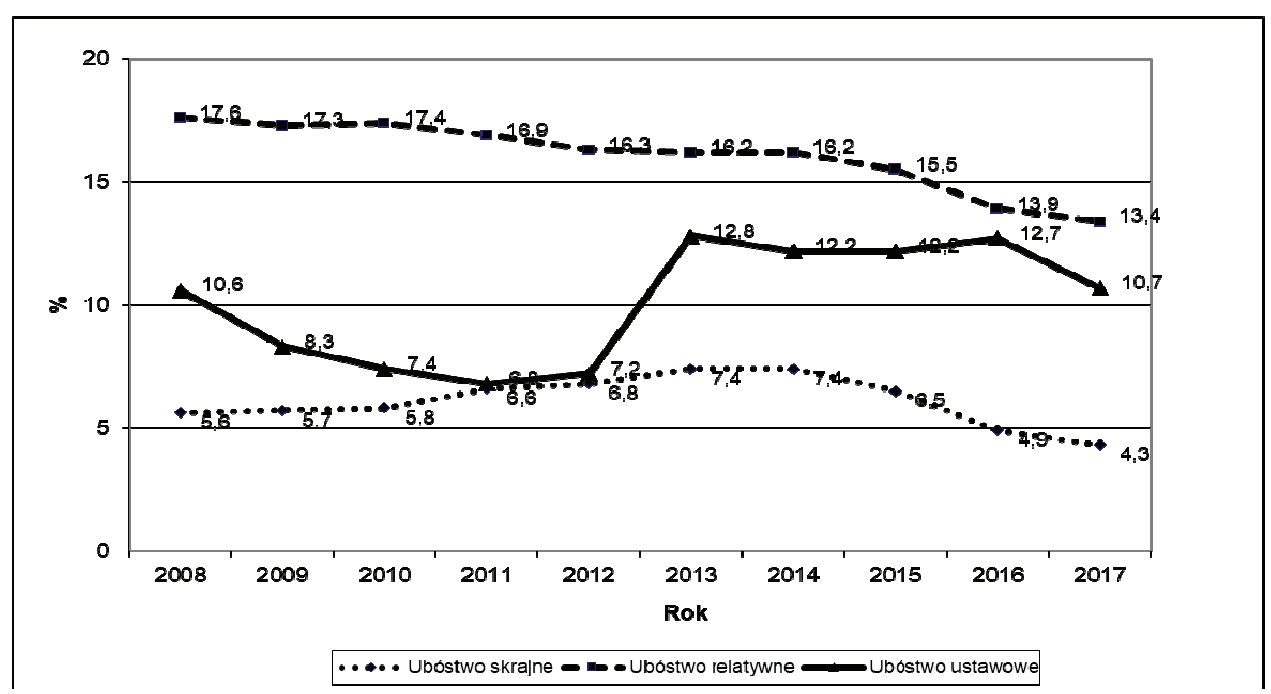

Wykres 1. Zasięg ubóstwa ekonomicznego w Polsce w latach 2008-2017

Źródło: opracowanie własne na podstawie danych GUS (Główny Urząd Statystyczny: Zasięg ubóstwa ekonomicznego w Polsce w latach 2008-2017, Warszawa 2009-2018).

Tabela 4. Zasięg ubóstwa skrajnego wg typów gospodarstw domowych i w gospodarstwach domowych z dziećmi w latach 2015-2017 (\% osób w gospodarstwach domowych)

\begin{tabular}{|c|c|c|c|c|c|}
\hline & Zasięg ubóstwa skrajnego & 2015 & \multicolumn{2}{|c|}{2016} & 2017 \\
\hline \multicolumn{2}{|c|}{ Gospodarstwa 1-osobowe } & 2,5 & \multicolumn{2}{|c|}{2,0} & 2,1 \\
\hline \multirow{5}{*}{ 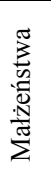 } & bez dzieci na utrzymaniu & 1,6 & \multicolumn{2}{|c|}{1,8} & 1,7 \\
\hline & z 1 dzieckiem & 1,8 & \multicolumn{2}{|c|}{1,7} & 1,3 \\
\hline & z 2 dzieci & 4,0 & \multicolumn{2}{|c|}{2,7} & 2,2 \\
\hline & z 3 dzieci & 9,0 & 4,7 & \multirow{2}{*}{$7,5^{\mathrm{a}}$} & \multirow{2}{*}{$6,4^{\mathrm{a}}$} \\
\hline & z co najmniej 4 dzieci na utrzymaniu & 18,1 & 14,0 & & \\
\hline & matka lub ojciec $\mathrm{z}$ dziećmi na utrzymaniu & 6,5 & \multicolumn{2}{|c|}{5,6} & 2,5 \\
\hline \multicolumn{6}{|c|}{ Gospodarstwa domowe $\mathrm{z}$ dziećmi w wieku 0-17 lat } \\
\hline \multicolumn{2}{|c|}{ z co najmniej 1 dzieckiem w wieku 0-17 lat } & 8,8 & \multicolumn{2}{|c|}{5,9} & 4,9 \\
\hline \multicolumn{2}{|c|}{ z dokładnie 1 dzieckiem w wieku 0-17 lat } & 5,3 & \multicolumn{2}{|c|}{4,3} & 3,8 \\
\hline \multicolumn{2}{|c|}{$\mathrm{z}$ dokładnie 2 dzieci w wieku 0-17 lat } & 8,1 & \multicolumn{2}{|c|}{5,3} & 4,5 \\
\hline \multicolumn{2}{|c|}{ z co najmniej 3 dzieci w wieku 0-17 lat } & 16,7 & \multicolumn{2}{|c|}{9,9} & 7,6 \\
\hline \multicolumn{2}{|c|}{ bez dzieci w wieku 0-17 } & 3,7 & \multicolumn{2}{|c|}{3,7} & 3,6 \\
\hline
\end{tabular}

${ }^{a}-z$ co najmniej 3 dzieci na utrzymaniu

Źródło: opracowanie własne na podstawie danych GUS (Główny Urząd Statystyczny: Zasięg ubóstwa ekonomicznego w Polsce w latach 2008-2017, Warszawa 2009-2018). 
Z dużym prawdopodobieństwem można stwierdzić, że obserwowane zmiany związane były $\mathrm{z}$ poprawą sytuacji materialnej gospodarstw domowych, co w konsekwencji spowodowało spadek zasięgu ubóstwa skrajnego i relatywnego. Był to okres, kiedy można mówić o zakończeniu kryzysu finansowego i początku ożywienia gospodarczego, któremu towarzyszyły wzrost wynagrodzeń oraz spadek bezrobocia. Dodatkowo na poprawę sytuacji materialnej gospodarstw domowych w szczególności rodzin z dziećmi (szczególnie rodzin wielodzietnych) wpłynęła polityka państwa i wprowadzenie w 2016 r. programu „Rodzina 500+”. To właśnie w przypadku tej grupy zasięg ubóstwa skrajnego zmniejszył się w największym stopniu (tabela 4). W przypadku ubóstwa ustawowego wpływ na zmniejszenie się jego zasięgu miała nie tylko poprawa sytuacji materialnej, lecz również fakt, że od IV kwartału 2015 r. nie zmienił się poziom granic omawianego ubóstwa (tabela 3).

\section{Metoda badań i rezultaty}

W celu zbadania zależności pomiędzy wydatkami z budżetu państwa na realizację zadań związanych z pomoca społeczną (działy: Pomoc społeczna, Pozostałe zadania w zakresie polityki społecznej, Rodzina), a zasięgiem ubóstwa skrajnego, ubóstwa relatywnego oraz ubóstwa ustawowego wyznaczono współczynnik korelacji liniowej Pearsona. Analiza została przeprowadzona na podstawie danych statystycznych za lata 2008-2017 pochodzących ze sprawozdań z wykonania budżetu państwa oraz danych GUS. Analizy statystyczne zostały wykonane z wykorzystaniem oprogramowania Statistica oraz Microsoft Excel.

Tabela 5. Zależność pomiędzy wydatkami z budżetu państwa na zadania w zakresie polityki społecznej a wskaźnikami ubóstwa skrajnego, relatywnego i ustawowego

\begin{tabular}{|c|c|c|c|}
\hline Wyszczególnienie & $\begin{array}{c}\text { Ubóstwo skrajne } \\
(\mathrm{w} \%)\end{array}$ & $\begin{array}{c}\text { Ubóstwo relatywne } \\
(\mathrm{w} \%)\end{array}$ & $\begin{array}{c}\text { Ubóstwo } \\
\text { ustawowe }(\mathrm{w} \%)\end{array}$ \\
\hline $\begin{array}{c}\text { Wydatki z budżetu państwa na realizację } \\
\text { zadań związanych z pomocą społeczną }\end{array}$ & $-0,744770^{\mathrm{a}}$ & $-0,912871^{\mathrm{a}}$ & 0,381524 \\
\hline
\end{tabular}

${ }^{\mathrm{a}} \mathrm{p}<0,05$

Źródło: opracowanie własne.

Na podstawie analizy danych z lat 2008-2017 stwierdzono, że wydatki w działach Pomoc spoleczna, Pozostałe zadania w zakresie polityki społecznej oraz dziale Rodzina są ujemnie skorelowane ze wskaźnikami ubóstwa skrajnego oraz ubóstwa relatywnego. Współczynnik korelacji pomiędzy analizowanymi wydatkami a poziomem ubóstwa skrajnego wynosi $-0,7447$, wartość ta jest istotna statystycznie na poziomie $5 \%$. W przypadku ubóstwa relatywnego współczynnik korelacji wynosi $-0,912 \quad(\mathrm{p}<0,05)$. Korelacja między wydatkami i wskaźnikiem ubóstwa ustawowego wynosi 0,381 , ale wartość ta nie jest istotna statystycznie.

Następnie za pomocą analizy statystycznej sprawdzono, w jakim stopniu wzrost wydatków z budżetu państwa na Pomoc spoleczna, Pozostałe zadania w zakresie polityki spolecznej oraz Rodzine wpływa na poziom wskaźników ubóstwa ekonomicznego, takich jak: wskaźnik ubóstwa skrajnego, wskaźnik ubóstwa relatywnego oraz wskaźnik ubóstwa ustawowego. W tym celu skonstruowano modele regresji liniowej dwóch zmiennych. 
Oszacowano zatem liniowe funkcje regresji następującej postaci:

$$
Y=\alpha_{0}+\alpha_{1} \cdot X+\varepsilon
$$

gdzie Y jest zmienną zależną, $\mathrm{X}$ zmienną niezależną, $\alpha_{0}, \alpha_{1}$ to parametry liniowej funkcji regresji, a $\varepsilon$ jest składnikiem losowym. Za zmienną objaśnianą $Y$ przyjęto kolejno wskaźnik ubóstwa skrajnego, wskaźnik ubóstwa relatywnego oraz wskaźnik ubóstwa ustawowego. Zmienną objaśniającą $X$ we wszystkich rozważanych modelach regresji będą stanowiły wydatki z budżetu państwa na Pomoc społeczna, Pozostałe zadania w zakresie polityki społecznej oraz w dziale Rodzina.

Oczekuje się, że wyższe wydatki budżetowe w analizowanych działach będą przyczyniały się do spadku zasięgu ubóstwa ekonomicznego wyrażonego w formie trzech wyżej wymienionych wskaźników.

Wyniki estymacji liniowych modeli regresji zostały przedstawione w tabelach 6-8. Wartości statystyk testowych $\mathrm{F}$ oraz wartości prawdopodobieństw testowych p-value w testach F (por. tabele 6-8) wskazują na statystyczną istotność dwóch z trzech funkcji regresji na poziomie istotności 0,05 . Statystycznie nieistotna okazała się funkcja regresji liniowej wskaźnika ubóstwa ustawowego względem wydatków z budżetu państwa na zadania związane $\mathrm{z}$ pomocą społeczną oraz $\mathrm{w}$ dziale rodzina ( $\mathrm{p}$-value $\mathrm{w}$ teście $\mathrm{F}$ wynosi 0,276, por. tabela 8). Dokładność oszacowania otrzymanych funkcji regresji liniowej można także ocenić za pomocą odchylenia standardowego składnika resztowego (losowego) oraz współczynnika determinacji. Współczynniki determinacji $R^{2}$ w oszacowanych funkcjach regresji nie przekraczają 84\%. Najwyższy współczynnik determinacji $R^{2} \quad 83,33 \%$ zaobserwowano dla funkcji regresji liniowej wskaźnika ubóstwa relatywnego względem wydatków z budżetu w działach związanych z pomocą społeczną i rodziną (zob. tabela 7). Na podstawie tej miary możemy wywnioskować, że w sensie przyjętej funkcji regresji ok. 83\% zmienności wskaźnika ubóstwa relatywnego zostało wyjaśnione zmiennością wydatków $\mathrm{z}$ budżetu państwa $\mathrm{w}$ analizowanych działach. W przypadku funkcji regresji liniowej wskaźnika ubóstwa skrajnego względem wydatków z budżetu w działach związanych z pomocą społeczną i rodziną (zob. tabela 6) współczynnik determinacji wynosi $R^{2} 55,47 \%$, co oznacza, że ok. 55\% zmienności wskaźnika ubóstwa skrajnego zostało wyjaśnione zmiennością wydatków z budżetu państwa. Natomiast dla wyznaczonej funkcji regresji liniowej wskaźnika ubóstwa ustawowego względem wydatków z budżetu w działach związanych z pomocą społeczną i rodziną (zob. tabela 8 ) współczynnik determinacji $R^{2}$ wynosi jedynie $14,56 \%$ i model jest nieistotny $(\mathrm{p}=0,276)$.

Można zatem stwierdzić, że liniowe zależności między wydatkami z budżetu państwa $\mathrm{w}$ działach dotyczących pomocy społecznej i rodziny a dwoma zmiennymi zależnymi będącymi wskaźnikami ubóstwa (skrajnego i relatywnego) są statystycznie istotne i są to zależności silne bądź umiarkowane.

Współczynnik kierunkowy pierwszego analizowanego modelu (dla ubóstwa skrajnego) wynosi -0,07, co oznacza, że wzrost wydatków budżetu państwa w działach związanych z pomocą społeczną i w dziale rodzina o $1 \mathrm{mld}$ zł powoduje spadek zasięgu ubóstwa skrajnego o 0,07 p.p. Natomiast w przypadku ubóstwa relatywnego współczynnik kierunkowy modelu wynosi -0,11. Oznacza to, że jeśli analizowane wydatki budżetowe wzrosną o $1 \mathrm{mld}$, to nastąpi spadek tego wskaźnika o 0,11 p.p. 
Tabela 6. Oceny parametrów liniowego modelu regresji wskaźnika ubóstwa skrajnego względem wydatków budżetu państwa w działach związanych z pomocą społeczną i w dziale rodzina

\begin{tabular}{|c|c|c|c|c|c|}
\hline & \multicolumn{5}{|c|}{ Wyniki regresji } \\
\hline & Parametr & $\begin{array}{l}\text { Średni błąd } \\
\text { szacunku }\end{array}$ & $\begin{array}{l}\text { Wartość } \\
\text { statystyki } \\
\text { testowej t }\end{array}$ & df & p-value \\
\hline Wyraz wolny & 7,5916 & 0,5253 & 14,4519 & 8 & $5,14 \mathrm{E}-07$ \\
\hline $\begin{array}{l}\text { Współczynnik kierunkowy } \\
\text { regresji }\end{array}$ & $-0,0665$ & 0,0211 & $-3,1567$ & 8 & 0,0135 \\
\hline & \multicolumn{5}{|c|}{ Ocena dopasowania modelu } \\
\hline $\begin{array}{c}\text { Odchylenie standardowe } \\
\text { składnika resztowego (błąd } \\
\text { standardowy modelu) }\end{array}$ & 0,7257 & & & & \\
\hline $\begin{array}{l}\text { Współczynnik determinacji } \\
\text { Wartość statystyki testowej F } \\
\text { p-value w teście F }\end{array}$ & $\begin{array}{l}0,5547 \\
9,9647 \\
0,0135\end{array}$ & & & & \\
\hline
\end{tabular}

Źródło: opracowanie własne.

Tabela 7. Oceny parametrów liniowego modelu regresji wskaźnika ubóstwa relatywnego względem wydatków budżetu państwa w działach związanych z pomocą społeczną i w dziale rodzina

\begin{tabular}{|c|c|c|c|c|c|}
\hline & \multicolumn{5}{|c|}{ Wyniki regresji } \\
\hline & $\begin{array}{c}\text { Wartość } \\
\text { współczynnika }\end{array}$ & $\begin{array}{l}\text { Średni błąd } \\
\text { szacunku }\end{array}$ & $\begin{array}{l}\text { Wartość } \\
\text { statystyki } \\
\text { testowej t }\end{array}$ & df & p-value \\
\hline Wyraz wolny & 18,6310 & 0,4501 & 41,3887 & 8 & $1,27903 \mathrm{E}-10$ \\
\hline $\begin{array}{l}\text { Współczynnik kierunkowy } \\
\text { regresji }\end{array}$ & $-0,1141$ & 0,0180 & $-6,3246$ & 8 & 0,0002 \\
\hline & \multicolumn{5}{|c|}{ Ocena dopasowania modelu } \\
\hline $\begin{array}{c}\text { Odchylenie standardowe } \\
\text { składnika resztowego (błąd } \\
\text { standardowy modelu) }\end{array}$ & 0,6218 & & & & \\
\hline $\begin{array}{l}\text { Współczynnik determinacji } \\
\text { Wartość statystyki testowej F } \\
\text { p-value w teście F }\end{array}$ & $\begin{array}{c}0,8333 \\
40,0002 \\
0,0002 \\
\end{array}$ & & & & \\
\hline
\end{tabular}

Źródło: opracowanie własne.

Tabela 8. Oceny parametrów liniowego modelu regresji wskaźnika ubóstwa ustawowego względem wydatków budżetu państwa w działach związanych z pomocą społeczną i w dziale rodzina

\begin{tabular}{|c|c|c|c|c|c|}
\hline \multirow{2}{*}{} & \multicolumn{4}{|c|}{ Wyniki regresji } & \\
\cline { 2 - 5 } & $\begin{array}{c}\text { Wartość } \\
\text { współczynnika }\end{array}$ & $\begin{array}{c}\text { Średni błąd } \\
\text { szacunku }\end{array}$ & $\begin{array}{c}\text { Wartość } \\
\text { statystyki } \\
\text { testowej }\end{array}$ & df & p-value \\
\hline Wyraz wolny & 8,2761 & 1,7273 & 4,7913 & 8 & 0,0014 \\
\hline $\begin{array}{c}\text { Współczynnik kierunkowy } \\
\text { regresji }\end{array}$ & 0,0808 & 0,0692 & 1,1674 & 8 & 0,2767 \\
\hline $\begin{array}{c}\text { Odchylenie standardowe } \\
\text { składnika resztowego (błąd } \\
\text { standardowy modelu) }\end{array}$ & 2,3861 & Ocena dopasowania modelu & \\
\hline Współczynnik determinacji & 0,1456 & & \\
Wartość statystyki testowej F \\
p-value w teście F
\end{tabular}

Źródło: opracowanie własne. 
Wyniki empiryczne estymacji modeli regresji liniowej szczególnie dla ubóstwa ustawowego, w tym niska wartość współczynnika determinacji, wskazuje, że zaproponowane równanie regresji liniowej nie stanowi jeszcze dobrego przybliżenia zależności liniowych między wydatkami budżetu państwa w działach związanych z pomocą społeczną i w dziale Rodzina a wskaźnikiem ubóstwa ustawowego (w mniejszym stopniu wskaźnikiem ubóstwa skrajnego) ${ }^{40}$. Pokazują natomiast, że dość znaczną rolę w wyjaśnianiu zmienności poszczególnych wskaźników odgrywa zmienna „wydatki budżetu państwa $\mathrm{w}$ działach związanych $\mathrm{z}$ pomoca społeczną $\mathrm{i}$ w dziale Rodzina". Aby sprawdzić, jakie inne zmienne, oprócz analizowanych wydatków, odgrywają jeszcze istotną rolę w wyjaśnianiu zmienności poszczególnych wskaźników, należy oszacować np. modele ekonometryczne $\mathrm{z}$ większą liczbą zmiennych objaśniających.

\section{Podsumowanie}

Polityka społeczna jest jednym z kluczowych zadań państwa ${ }^{41}$ mającym na celu m.in. wspieranie osób i rodzin na wielu płaszczyznach, przede wszystkim: znajdujących się w trudnej sytuacji materialnej i społecznej, w tym rodzin niepełnych, wielodzietnych lub z osobami niepełnosprawnymi, a także osób i rodzin zagrożonych wykluczeniem społecznym. Istotny element polityki społecznej stanowi aktywizacja zawodowa, zwłaszcza osób starszych, długotrwale bezrobotnych i niepełnosprawnych. Przeciwdziałanie wykluczeniu dotyczy zarówno rodzin jak i osób samotnych, dlatego konkretne wsparcie związane jest również z aktywnym i godnym życiem w środowisku społecznym, pomocą dla osób chorych, bezdomnych, kombatantów i osób represjonowanych. W ostatnich latach (2012-2017) polityka społeczna w zakresie ograniczania ubóstwa zaczęła odgrywać coraz istotniejszą rolę. Było to możliwe dzięki wprowadzeniu nowych programów rządowych, co bezpośrednio skutkowało z jednej

\footnotetext{
${ }^{40}$ Ustawowa granica jest wynikiem sposobu ustalania progu interwencji socjalnej, którego sposób obliczania jest określony w Rozporządzeniu Ministra Polityki Społecznej z dnia 7 października 2005 r. w sprawie progu interwencji socjalnej. W świetle cytowanych przepisów (§ 3. 1.) „Próg interwencji socjalnej jest ustalany w oparciu o koszyk dóbr i ustug opracowany na podstawie minimalnych norm spożycia, minimalnych okresów użytkowania dóbr oraz minimalnego zakresu korzystania z ustug, wyrażony wartościami cen rynkowych w przyjętym okresie badawczym, a nastęnie korygowany o rzeczywiste zachowania konsumpcyjne wybranych typów gospodarstw domowych o niskich dochodach”. Co więcej „Zakres potrzeb niezbędnych do egzystencji branych pod uwage przy ustalaniu progu interwencji socjalnej obejmuje wydatki na: żywność; mieszkanie; odzież i obuwie; edukację, ochronę zdrowia i higienę, transport $i$ taczność oraz kulturę, sport $i$ wypoczynek (§ 3. 3). Natomiast ustawa z dnia 12 marca 2004 r. o pomocy społecznej (Dz. U. 2019, poz. 1507 ze zm.) w art. 9 ust. 1 stanowi, że kryteria dochodowe podlegają weryfikacji co trzy lata z uwzględnieniem wyniku badań progu interwencji socjalnej". W konsekwencji granica ubóstwa ustawowego nie jest efektem jedynie rzeczywistych wydatków gospodarstw domowych czy potrzeb, których zaspokojenie nie może być odłożone w czasie, ale również wynikiem określonej decyzji ministra właściwego ds. zabezpieczenia społecznego. W powiązaniu z trzyletnim okresem weryfikacji interwencji socjalnej, w praktyce oznacza to, że granica ubóstwa ustawowego ustalana jest w oparciu o inne zasady (niż pozostałe dwie granice ubóstwa), co może być powodem braku zależności pomiędzy wydatkami budżetowymi a ubóstwem ustawowym. Uzasadnienie to wymagałoby szerszego wywodu, jednak ze względu na ograniczone ramy opracowania, nie zamieszczono go w artykule.

${ }^{41}$ Należy jednak podkreślić, że istnieją różne modele polityki społecznej (m.in. konserwatywny, liberalny i socjaldemokratyczny), gdzie rola państwa jest zróżnicowana (B. Balcerzak-Paradowska: Ogólne tendencje..., op. cit., s. 15).
} 
strony, wzrostem wydatków publicznych, a z drugiej, spadkiem zasięgu ubóstwa. W szczególności zaobserwowano spadek ubóstwa w przypadku rodzin wielodzietnych $\mathrm{W}$ rezultacie przeprowadzonych badań $\mathrm{z}$ wykorzystaniem analizy statystycznej stwierdzono, że wzrost wydatków publicznych wpływa na poziom ubóstwa w Polsce zmniejszając jego zasięg. $W$ ramach wniosków płynących $\mathrm{z}$ badań odnotowano, że liniowe zależności między wydatkami $\mathrm{z}$ budżetu państwa $\mathrm{w}$ działach dotyczących polityki społecznej i rodziny a dwoma zmiennymi zależnymi będącymi wskaźnikami ubóstwa (skrajnego i relatywnego) są statystycznie istotne i są to zależności silne bądź umiarkowane. Oznacza to, że w przypadku wymienionych rodzajów ubóstwa, zwiększone wydatki publiczne w działach $852,853,855$ spowodowały ograniczenie zasięgu ubóstwa.

Na zakończenie warto zauważyć, że przeprowadzone badania mogą stanowić podstawę do dalszych, pogłębionych analiz. W aspekcie teoretycznym interesujące wydają się być rozważania dotyczące problemu ubóstwa wśród osób starszych. Można również zadać pytanie, w jaki sposób państwo powinny realizować politykę społeczną, aby wpływać na jakość życia osób starszych. Warto również zweryfikować sformułowane tutaj wnioski w oparciu o badania zróżnicowania zasięgu ubóstwa w poszczególnych województwach oraz w skali międzynarodowej.

\section{Literatura}

Balcerzak-Paradowska B: Rodzina i polityka rodzinna na przełomie wieków: przemiany, zagrożenia potrzeba działań, Instytut Pracy i Spraw Socjalnych, Warszawa 2004.

Balcerzak-Paradowska B.: Ogólne tendencje w polityce rodzinnej UE, [w:] Polityka rodzinna w krajach Unii Europejskiej - wnioski dla Polski, B. Balcerzak-Paradowska, J. Szymborski (red.), Biuletyn Rzecznika Praw Obywatelskich - Materiały Nr 67, Warszawa 2009.

Durasiewicz A.: Instrumenty polityki rodzinnej, „Biuletyn Informacyjny. Wiadomości Społeczne” Nr 1, K. Głąbicka (red.), Polskie Towarzystwo Polityki Społecznej, Warszawa 2009, s. 57-70.

Komisja Europejska: Europejska platforma współpracy w zakresie walki $\mathrm{z}$ ubóstwem i wykluczeniem społecznym: europejskie ramy na rzecz spójności społecznej i terytorialnej, Komunikat Komisji do Parlamentu Europejskiego, Rady, Europejskiego Komitetu EkonomicznoSpołecznego oraz Komitetu Regionów, KOM(2010) 758 wersja ostateczna, Bruksela 2010.

Eurostat: Smarter, greener, more inclusive? Indicators to support the Europe 2020 strategy, Publications Office of the European Union, Luxembourg 2016.

Główny Urząd Statystyczny: Zasięg ubóstwa ekonomicznego w Polsce w latach 2008-2017, Warszawa 2009-2018.

Kokoszkiewicz A.: Opieka społeczna jako zadanie państwa. Studium teoretycznoprawne, Wydawnictwo Europejskiej Fundacji Przedsiębiorczości, Lublin 2015.

Konstytucja Rzeczypospolitej Polskiej z dnia 2 kwietnia 1997 r., Dz.U. 1997, nr 78, poz. 483.

Kurzynowski A.: Problemy rodziny w polityce społecznej, Ośrodek Badań Społecznych, Warszawa 1991.

Kurzynowski A.: Związki polityki społecznej z polityką gospodarczą, [w:] Kurzynowski A. red. Polityka społeczna, Szkoła Główna Handlowa, Warszawa 2001.

Lecerf, M.: Poverty in the European Union. The crisis and its aftermath, European Parliamentary Research Service, European Parliament: Directorate-General for Parliamentary Research Services, European Union 2016.

OECD: The OECD List of Social Indicators, OECD: Paris 1982.

Orczyk J.: Ewolucja polityki społecznej w Polsce po 1990 r., [w:] Współczesne obrazy polityki społecznej i gospodarczej. Księga pamiątkowa dedykowana Profesor Lucynie Frąckiewicz, 
„Studia Ekonomiczne”, Zeszyty Naukowe Wydziałowe Uniwersytetu Ekonomicznego w Katowicach, W. Koczur, A. Rączaszek (red.), Katowice 2012, s. 31-44.

Panek, T., Zwierzchowski, J.: Porównawcza analiza sfery ubóstwa w krajach UE w ujęciu regionalnym, Zeszyty Naukowe Instytutu Statystyki i Demografii SGH, Warszawa 2013, s. 1-117. Rada Ministrów: Uzasadnienie do projektu ustawy budżetowej w układzie zadaniowym na lata 2008-2019, Warszawa 2007-2018.

Rada Ministrów: Sprawozdanie z wykonania budżetu państwa za lata 2008-2017, Warszawa 2009-2018 .

Rada Ministrów: Krajowy Program Reform, Warszawa 2011.

Rada Ministrów: Uchwała Nr 157 Rady Ministrów z dnia 25 września 2012 r. w sprawie przyjęcia Strategii Rozwoju Kraju 2020, M. P. 2012, poz. 882.

Rada Ministrów: Uchwała Nr 61 Rady Ministrów z dnia 26 marca 2013 r. w sprawie przyjęcia „Strategii Rozwoju Kapitału Społecznego 2020”, M.P. 2013, poz. 378.

Rada Ministrów: Uchwała Nr 104 Rady Ministrów z dnia 18 czerwca 2013 r. w sprawie przyjęcia Strategii Rozwoju Kapitału Ludzkiego 2020, M.P. 2013, poz. 640.

Rada Ministrów: Krajowy Program Reform na rzecz realizacji strategii „Europa 2020” Aktualizacja KPR 2013/2014, Warszawa 2013.

Rada Ministrów: Uchwała Rady Ministrów nr 165 z dnia 12 sierpnia 2014 r. w sprawie przyjęcia programu pod nazwą „Krajowy Program Przeciwdziałania Ubóstwu i Wykluczeniu Społecznemu 2020. Nowy wymiar aktywnej integracji”, M.P. 2014, poz. 787.

Rada Ministrów: Uchwała nr 8 Rady Ministrów z dnia 14 lutego 2017 r. w sprawie przyjęcia Strategii na rzecz Odpowiedzialnego Rozwoju do roku 2020 (z perspektywą do 2030 r.), M.P. 2017 poz. 260.

Sen, A.: Social Exclusion: concept, application and scrutiny. Social Development Papers, 1, Manila: Asian Development Bank, 2000, s. 1-54.

Sierpowska I.: Wprowadzenie [w:] Pomoc społeczna, Lex a Wolters Kluwer business, Warszawa 2011.

Sierpowska I.: Bezpieczeństwo socjalne jako dobro publiczne, Zeszyty Naukowe Państwowej Wyższej Szkoły Zawodowej im. Witelona w Legnicy 2015, Nr 16(3).

Stecko S.: Polityka społeczna państwa względem rodziny, „Społeczeństwo i Rodzina” 2017, Nr 50, s. 139-151.

Supińska J.: Debaty o polityce społecznej, Oficyna Wydawnicza ASPRA-JR, Warszawa 2013.

Szarfenberg R.: Ubóstwo i wykluczenie społeczne w Polsce. Pomiar, wyjaśnianie, strategie przeciwdziałania, Friedrich-Ebert-Stiftung, Przedstawicielstwo w Polsce wspólnie z Fundacją Międzynarodowe Centrum Badań i Analiz (ICRA ), Warszawa 2012.

Szatur-Jaworska B.: Polityka socjalna [w:] W kręgu pojęć i zagadnień współczesnej polityki społecznej, B. Rysz-Kowalczyk, B. Szatur-Jaworska (red.), Instytut Polityki Społecznej, Wydawnictwo Uniwersytetu Warszawskiego, Warszawa 2016.

Tkaczuk, M.: Polska polityka społeczna na progu członkostwa w Unii Europejskiej, „Roczniki Nauk Społecznych” 2006, zeszyt 3, tom XXXIV, s. 209-218.

Ustawa z dnia 12 marca 2004 r. o pomocy społecznej, Dz.U. 2004, nr 64, poz. 593 ze zm.

Ustawa z dnia 5 grudnia 2014 r. o Karcie Dużej Rodziny, Dz. U. 2014, poz. 1863 ze zm.

Ustawa z dnia 11 lutego 2016 r. o pomocy państwa w wychowywaniu dzieci, Dz.U. 2016, poz. 195.

Ustawa z dnia 4 listopada 2016 r. o wsparciu kobiet w ciąży i rodzin „Za życiem", Dz. U. 2016, poz. $1860 \mathrm{ze} \mathrm{zm}$.

\section{Abstract}

The problem of poverty and social exclusion has become extremely important in the wake of the financial and economic crisis of 2008. The study assesses the institutional and legal forms of social 
assistance that were implemented in Poland. The main objective of the study is to examine the dependence between state budget expenditures for the implementation of social assistance and the extent of poverty in Poland. As a result of the conducted research using statistical analysis, it was found that an increase in public expenditure influences the level of poverty in Poland, reducing its range. As part of the conclusions drawn from the research, it was noted that linear dependencies between expenditures from the state budget in the spheres of social and family policy, and two dependent variables that are indicators of poverty (extreme and relative), are statistically significant and have strong or moderate dependence.

Keywords: state financial policy, poverty, social exclusion, social assistance.

JEL Codes: G28, H53, I38.

$\underline{\text { Informacje o autorach }}$

Dr Katarzyna Maj-Waśniowska

e-mail: majk@uek.krakow.pl

ORCID: 0000-0003-0312-3359

Dr Katarzyna Stabryła-Chudzio

e-mail: stabrylk@poczta.uek.krakow.pl ORCID: 0000-0001-9975-1899'

Uniwersytet Ekonomiczny w Krakowie

Instytut Finansów

ul. Rakowicka 27, 31-510 Kraków, Polska 